\title{
Evaluation of Vomiting Among Children Admitted to Al-Azhar University Hospital in Assiut
}

\author{
Abdelmagid Mohammad Bayomi, Hosny Abdel Kareem, Mohammad Ehab Saad Zaghloul* \\ Pediatrics Department, Faculty of Medicine, Al-Azhar University, Assiut, Egypt \\ *Corresponding Author: Mohammad Ehab Saad Zaghloul, Phone No.: (+2) 01026592091, \\ E-mail: drmohammadoraby@gmail.com
}

\begin{abstract}
Background: Vomiting is a common problem in children for which parents seek health care consultation. It has a varied etiology encompassing many organ systems, ranging from a benign physiological behavior to a life-threatening systemic disease. Most often, it is benign and self-limiting. Infections within and outside the gastrointestinal tract are the commonest causes. Objective: To evaluate the gastrointestinal and non-gastrointestinal causes of vomiting in children admitted to Al-Azhar University Hospital in Assiut from December 2019 to June 2020.

Patients and Methods: This descriptive cross-sectional study included 105 children admitted to Al- Azhar University Hospital in Assiut during the period from December 2019 to June 2020 presenting with vomiting. Their ages varied from 2 to 10 years old and included 64 males and 41 females. Results: Acute gastroenteritis was the leading cause of vomiting among all cases. It was observed that dehydration (86.0\%) and weight loss $(70.2 \%)$ were the most common clinical signs among GI causes of vomiting. Regarding laboratory results, anemia was presented in most of our cases, due to GI and non-GI causes of vomiting, representing (82.4\%) and (70.8\%) respectively. Abdominal U/S showed a high ability in diagnosing renal stones in $(12.5 \%)$ of cases with non-GI causes of vomiting.

Conclusion: The commonest GI cause of vomiting in children was gastroenteritis, followed by hepatitis A infection. The commonest non-GI cause of vomiting was lower respiratory tract infection. Weight loss was considered a golden standard in assessment of dehydration. Abdominal U/S was a useful tool for the diagnosis of renal stones.
\end{abstract}

Keywords: Vomiting, H. pylori infection, Acute gastritis, Gastroenteritis.

\section{INTRODUCTION}

Vomiting is a common symptom of numerous underlying conditions for which children frequently present for healthcare. Although vomiting can originate from the gastrointestinal (GI) tract itself, it can also signal more generalized, systemic disorders. Vomiting in children is often benign and can be managed with supportive measures only. Still, clinicians must be able to recognize life-threatening causes of vomiting and to avoid serious associated complications, including electrolyte abnormalities, dehydration, or even bowel necrosis ${ }^{(\mathbf{1})}$.

A variety of organic and non-organic disorders can be associated with vomiting. Organic causes are those related to specific medical conditions. The primary care practitioner needs to remember that vomiting does not localize the problem to the GI system in young infants but can be a non-specific manifestation of an underlying systemic illness such as a urinary tract infection, sepsis, or an inborn error of metabolism. Nonorganic causes are much more difficult to identify and often are viewed as diagnoses of exclusion. Examples of non-organic causes of vomiting are psychogenic vomiting, cyclic vomiting syndrome, abdominal migraine, and bulimia ${ }^{(2)}$.

Red flags include unstable vital signs, acidotic breathing, presence of bile or bloodstained vomitus, features of gastrointestinal (GI) obstruction, encephalopathy and papilledema. Blood pressure, hydration status, careful abdominal examination including genitalia and hernial orifices and fundus form important components of the physical examination.
Signs of GI obstruction should prompt an abdominal Xray and surgical consultation ${ }^{(3)}$.

Recognition and treatment of the underlying cause is important. Mere symptomatic treatment may delay specific diagnosis and therapy. If the cause is not apparent after initial assessment, observation and/or admission would be appropriate.

Vomiting may need symptomatic relief with antiemetics, if it is persistent and impedes oral intake. Domperidone and ondansetron are the commonly used antiemetics. Since most causes are benign, parental reassurance with or without symptomatic treatment may suffice ${ }^{(3)}$.

This study aimed to evaluate the gastrointestinal and non-gastrointestinal causes of vomiting in children admitted to Al-Azhar University Hospital in Assiut from December 2019 to June 2020.

\section{PATIENTS AND METHODS}

This descriptive cross-sectional study included 105 children admitted to Al-Azhar University Hospital in Assiut during the period from December 2019 to June 2020 presenting with vomiting. Their age varied from 2 years to 10 years old. They were 64 males and 41 females.

Inclusion criteria: All cases presented with vomiting either isolated or associated with other symptoms from age of 2 to 10 years old and admitted to Al-Azhar University Hospital in Assiut.

Exclusion criteria: Neonates and children less than 2 years and older than 10 years were excluded. 
All children enrolled in this study were subjected to a full history and clinical examination, which included age, sex, weight, vomiting, diarrhea, abdominal distention, respiratory symptoms, sore throat, dysuria, polyuria, urinary output, signs of increased intracranial tension, convulsions, fever, hemodynamic stability, dehydration, abdominal tenderness, bowel sounds and neurological, cardiac, chest and abdominal examinations.

\section{All cases were subjected to the following investigations:}

Complete blood picture, serum creatinine, serum electrolytes, random blood glucose, and arterial blood gases. The following investigations were done according to clinical symptoms and signs associated with vomiting in every case as liver enzymes, pancreatic amylase, urine analysis, cerebrospinal fluid and blood cultures, CRP, chest X-ray, abdominal ultrasound and CT scan.

\section{Ethical approval and written informed consent:}

Approval of the study was obtained from AlAzhar University Academic Ethical Committee. Parents of every patient signed informed written consent for acceptance of the study.

\section{Statistical analysis}

Data were verified, coded by the researcher, and analyzed using IBM-SPSS Statistics for Windows, version 23.0 (Copyright IBM Corp., Armonk, N.Y., USA. 2015). Descriptive statistics were presented as means, standard deviations, medians, ranges, and percentages. Tests of significances: Chi-square test was used to compare the difference in the distribution of frequencies among different groups. For continuous variables, independent t-test analysis was carried out to compare the means of dichotomous data. There was no specific calculation of the sample size. A significant pvalue was considered when it is equal to or less than 0.05 .

\section{RESULTS}

Table (1): Demographic criteria of the studied children

\begin{tabular}{|l|l|}
\hline & Total N=105 \\
\hline $\begin{array}{l}\text { Age of children (Year) } \\
\text { Mean } \pm \text { SD) }\end{array}$ & $4.2 \pm 2.14$ \\
\hline Range (Min-Max) & $5(2-10)$ \\
\hline Gender & $\mathbf{N}(\%)$ \\
\hline Male & $64(61.0)$ \\
\hline Female & $41(39.0)$ \\
\hline
\end{tabular}

Table (1) showed that the mean age and gender of all patients.
Table (2): Classification of vomiting causes

\begin{tabular}{|l|l|l|}
\hline Causes & $\mathrm{N}$ & $(\%)$ \\
\hline GIT causes & 57 & 54.3 \\
\hline Non GIT causes & 48 & 45.7 \\
\hline
\end{tabular}

Table (2) divided the causes of vomiting whether they are from the gastrointestinal tract or not.

Table (3): Classification of causes of vomiting according to infectious causes

\begin{tabular}{|l|c|c|}
\hline Causes & $\mathrm{N}$ & $(\%)$ \\
\hline Infectious & 95 & 90.5 \\
\hline Non-infectious & 10 & 9.5 \\
\hline
\end{tabular}

Table (3) compared between causes of vomiting, whether they are caused by infection or not.

Table (4): Causes of vomiting according to GIT causes

\begin{tabular}{|l|c|c|}
\hline GIT causes & $\mathrm{N}=57$ & $(\%)$ \\
\hline Gastroenteritis & 43 & 75.4 \\
\hline Hepatitis A virus & 5 & 8.8 \\
\hline Appendicitis & 4 & 7.0 \\
\hline H. Pylori & 3 & 5.3 \\
\hline Pancreatitis & 2 & 3.5 \\
\hline
\end{tabular}

This table classified causes of vomiting that arise from the gastrointestinal tract (Table 4).

Table (5): Causes of vomiting according to non-GIT causes

\begin{tabular}{|l|c|c|}
\hline Non-GIT causes & $\mathrm{N}=48$ & $(\%)$ \\
\hline $\begin{array}{l}\text { LRTI (Bronchopneumonia/ } \\
\text { Bronchitis) }\end{array}$ & 13 & 27.1 \\
\hline CNS infection & 7 & 14.6 \\
\hline Pharyngitis/ Tonsilitis & 7 & 14.6 \\
\hline Otitis Media & 6 & 12.5 \\
\hline Renal stone & 6 & 12.5 \\
\hline Urinary tract infection & 5 & 10.4 \\
\hline DKA & 4 & 8.3 \\
\hline
\end{tabular}

Table (5) classified causes of vomiting that arise from systems other than the gastrointestinal tract. 
Table (6): Comparison of GIT and non-GIT causes of vomiting according to the age and gender

\begin{tabular}{|c|c|c|c|c|c|}
\hline & \multicolumn{2}{|c|}{$\begin{array}{c}\text { GIT } \\
\text { causes } \\
\mathrm{N}=57\end{array}$} & \multicolumn{2}{|c|}{$\begin{array}{c}\text { Non GIT } \\
\text { causes } \\
\mathrm{N}=48\end{array}$} & P-Value \\
\hline $\begin{array}{l}\text { Age (Year) } \\
(\text { Mean } \pm \text { SD) }\end{array}$ & \multicolumn{2}{|c|}{$\begin{array}{c}3.84 \pm \\
1.8\end{array}$} & \multicolumn{2}{|c|}{$4.36 \pm 2.42$} & $0.62 * \mathrm{NS}$ \\
\hline Gender & $\mathbf{N}$ & $(\%)$ & $\mathbf{N}$ & $(\%)$ & \\
\hline Male & 36 & 63.2 & 28 & 58.3 & \multirow{2}{*}{$0.61 * \mathrm{NS}$} \\
\hline Female & 21 & 36.8 & 20 & 41.7 & \\
\hline
\end{tabular}

Table (6) showed causes of vomiting in correlation with age and gender [Data were presented as Mean \pm SD and Freq (\%)]. *Independent sample t-test and Chi-square (x2) tests were used, NS: No statistically significant difference, $\mathrm{P}>0.05$.

Table (7): Associated symptoms of GIT and nonGIT causes of vomiting

\begin{tabular}{|l|c|c|c|c|c|}
\hline Symptoms & \multicolumn{2}{|c|}{$\begin{array}{c}\text { GIT } \\
\text { causes } \\
\text { N=57 }\end{array}$} & \multicolumn{2}{c|}{$\begin{array}{c}\text { Non GIT } \\
\text { causes } \\
\text { N=48 }\end{array}$} & P-value \\
\hline & N & $\%$ & N & $\%$ & \\
\hline Fever & 43 & 75.4 & 37 & 77.1 & $0.84 \mathrm{NS}^{*}$ \\
\hline Pallor & 15 & 26.3 & 17 & 35.4 & $0.3 \mathrm{NS}^{*}$ \\
\hline Jaundice & 4 & 7.0 & 0 & 0.0 & $0.61 \mathrm{NS}^{*}$ \\
\hline Irritability & 2 & 3.5 & 9 & 18.8 & $0.011 \mathrm{~S}^{*}$ \\
\hline Cough & 4 & 7.0 & 14 & 29.2 & $0.003 \mathrm{~S}^{*}$ \\
\hline $\begin{array}{l}\text { Abdominal } \\
\text { pain }\end{array}$ & 6 & 10.5 & 0 & 0.0 & $0.021 \mathrm{~S}^{*}$ \\
\hline Convulsions & 1 & 1.8 & 7 & 14.6 & $0.014 \mathrm{~S}^{*}$ \\
\hline Oliguria & 0 & 0.0 & 11 & 22.9 & $<0.001$ \\
\hline
\end{tabular}

Table (7) showed the percentage of the most common associated symptoms with vomiting [Data were presented as Freq and (\%)].

Chi-square $\left(\mathrm{x}^{2}\right)$, and *Fisher's Exact tests were used. S: Statistically significant difference, $\mathrm{P} \leq 0.05$. NS: No statistically significant difference, $\mathrm{P}>0.05$.
Table (8): Associated signs of GIT and non-GIT causes of vomiting

\begin{tabular}{|l|c|c|c|c|c|}
\hline \multicolumn{1}{|c|}{ Signs } & \multicolumn{2}{c|}{$\begin{array}{c}\text { GIT } \\
\text { causes } \\
\text { N=57 }\end{array}$} & \multicolumn{2}{c|}{$\begin{array}{c}\text { Non GIT } \\
\text { causes } \\
\text { N=48 }\end{array}$} & P-value \\
\hline N & $\%$ & N & $\%$ & \\
\hline Dehydration & 49 & 86.0 & 21 & 43.8 & $<0.001 \mathrm{~S}^{*}$ \\
\hline Weight loss > 5\% & 40 & 70.2 & 25 & 52.1 & $0.25 \mathrm{NS}^{*}$ \\
\hline $\begin{array}{l}\text { Altered mental } \\
\text { status }\end{array}$ & 9 & 15.8 & 4 & 8.3 & $0.057 \mathrm{NS}^{*}$ \\
\hline $\begin{array}{l}\text { Chest } \\
\text { Crepitations }\end{array}$ & 0 & 0.0 & 13 & 27.1 & $<0.001 \mathrm{~S}^{*}$ \\
\hline $\begin{array}{l}\text { Respiratory } \\
\text { distress }\end{array}$ & 1 & 1.8 & 7 & 14.6 & $0.014 \mathrm{~S}^{*}$ \\
\hline $\begin{array}{l}\text { Inflamed } \\
\text { Tympanic } \\
\text { Membrane }\end{array}$ & 0 & 0.0 & 7 & 14.6 & $0.003 \mathrm{~S}^{*}$ \\
\hline Hepatomegaly & 2 & 3.5 & 3 & 6.3 & $0.5 \mathrm{NS}^{*}$ \\
\hline Splenomegaly & 1 & 1.8 & 0 & 0.0 & $0.5 \mathrm{NS}^{*}$ \\
\hline
\end{tabular}

Table (8) showed the percentage of the most common associated signs with vomiting [Data wee presented as Freq and (\%)]. Chi-square $\left(\mathrm{x}^{2}\right)$, and *Fisher's Exact tests were used. S: Statistically significant difference, $\mathrm{P} \leq 0.05$. NS: No statistically significant difference, $\mathrm{P}>0.05$.

Table (9): Laboratory investigations of GIT and nonGIT causes of vomiting

\begin{tabular}{|l|c|c|c|c|c|}
\hline $\begin{array}{l}\text { Lab } \\
\text { investigations }\end{array}$ & \multicolumn{2}{|c|}{$\begin{array}{c}\text { GIT } \\
\text { causes } \\
\text { N=57 }\end{array}$} & \multicolumn{2}{c|}{$\begin{array}{c}\text { Non GIT } \\
\text { causes } \\
\text { N=48 }\end{array}$} & P-value \\
\hline N & $\%$ & N & $\%$ & \\
\hline Hypoglycemia & 11 & 19.3 & 4 & 8.3 & $<0.001^{* *}$ \\
\hline $\begin{array}{l}\text { Electrolytes } \\
\text { imbalance }\end{array}$ & 7 & 12.3 & 6 & 12.5 & 0.5 NS* \\
\hline $\begin{array}{l}\text { Increase liver } \\
\text { enzymes }\end{array}$ & 4 & 7.0 & 0 & 0.0 & 0.5 NS* \\
\hline $\begin{array}{l}\text { Positive H. pylori } \\
\text { antigen in stool }\end{array}$ & 3 & 5.0 & 0 & 0.0 & 0.16 NS* \\
\hline Anemia & 48 & 82.4 & 34 & 70.8 & 0.79 NS* \\
\hline Leukocytosis & 23 & 40.4 & 12 & 25.0 & 0.072 \\
& & & & & NS* \\
\hline
\end{tabular}

Table (9) demonstrated the lab results of all patients with vomiting [Data were presented as Freq 
and (\%)] Chi-square (x2), and *Fisher's Exact tests were used. S: Statistically significant difference, $\mathrm{P} \leq$ 0.05 . NS: No statistically significant difference, $\mathrm{P}>0.05$.

Table (10): Radiological findings of GIT non-GIT causes of vomiting

\begin{tabular}{|l|l|l|l|l|l|}
\hline $\begin{array}{l}\text { Radiological } \\
\text { findings }\end{array}$ & \multicolumn{2}{|c|}{$\begin{array}{c}\text { GIT } \\
\text { causes } \\
\text { N=57 }\end{array}$} & \multicolumn{2}{|c|}{$\begin{array}{c}\text { Non GIT } \\
\text { causes } \\
\text { N=48 }\end{array}$} & P-value \\
\hline & N & $\%$ & $\mathbf{N}$ & $\%$ & \\
\hline
\end{tabular}

\section{Chest radiography Findings}

\begin{tabular}{|l|l|l|l|l|l|}
\hline $\begin{array}{l}\text { Signs of } \\
\text { inflammation and } \\
\text { increase broncho- } \\
\text { vascular } \\
\text { markings }\end{array}$ & 0 & 0.0 & 13 & 27.1 & $<0.001^{*}$ \\
\hline
\end{tabular}

Abd. U/S Findings

\begin{tabular}{|l|c|c|c|c|c|}
\hline $\begin{array}{l}\text { Gaseous } \\
\text { Distention }\end{array}$ & 30 & $\begin{array}{c}52 . \\
6\end{array}$ & 0 & 0.0 & $0.006 \mathrm{~S}^{*}$ \\
\hline $\begin{array}{l}\text { Radio-opaque } \\
\text { stones (gall } \\
\text { bladder and/or } \\
\text { kidney) }\end{array}$ & 0 & 0.0 & 6 & 12.5 & $0.006 \mathrm{~S}^{*}$ \\
\hline
\end{tabular}

This table illustrated the radiological findings that were observed in patients with vomiting [Data presented as Freq and (\%)] Chi-square $\left(\mathrm{x}^{2}\right)$, and *Fisher's Exact tests were used. S: Statistically significant difference, $\mathrm{P} \leq 0.05$. NS: No statistically significant difference, $\mathrm{P}>0.05$.

\section{DISCUSSION}

In our study, it was found that the mean age of studied children was $4.2 \pm 2.14$ old. It was found that GI causes of vomiting represented $54.3 \%$, while non-GI causes of vomiting were $45.7 \%$. This agrees with Neil ${ }^{(4)}$ who stated that the most common cause of vomiting in the pediatrics is often GI.

The vast majority of children who presented with vomiting $(90.5 \%)$ were due to infectious causes. This is in agreement with Allen ${ }^{(5)}$ who stated that the most common cause of acute vomiting in children is infection, mainly viral gastroenteritis. Among all cases of vomiting due to GI causes, the etiology of vast majority of them was acute gastroenteritis representing $(74.4 \%)$. This may be due to bacterial, viral, parasitic or fungal infections. Viruses are the leading causes of acute gastroenteritis in children accounting for approximately $70-90 \%$ of cases according to Cherry et al. ${ }^{(6)}$. Bacteria as shigella, salmonella, campylobacter, enterotoxigenic E. coli, and less frequently enteroinvasive E. coli, are causative agents in $10-20 \%$ of cases ${ }^{(7)}$.
The second common GI cause of vomiting other than gastroenteritis was hepatitis A infection (8.8\%), This is concurrent with Kamel et al. ${ }^{\left({ }^{8}\right)}$ who reported that Egypt is considered an endemic country, it is estimated that there is a high prevalence of HAV circulating in Egypt.

Lower respiratory tract infection (acute pneumonia and acute bronchitis) was found in $27.1 \%$, presenting the most common cause of non-GI causes of vomiting. This agrees with Shields and Lightdale (1) who reported that post-tussive emesis is common in children and occurs due to increased abdominal pressure.

The clinical presentation showed that fever was the most common associated symptom in cases with vomiting due to GI causes $(75.4 \%)$. This could be attributed to infection. Pallor presented in $35.4 \%$ of non-GI causes of vomiting, which is mostly due to dehydration, as the other common symptoms were oliguria (22.9\%) and irritability (18.8\%). These symptoms together are used in assessment of dehydration according to WHO (9) scale of dehydration. It was observed that dehydration (86.0\%) and weight loss $(70.2 \%)$ were the most common clinical signs among GI causes of vomiting. Both signs are used to diagnose cases of acute gastroenteritis according to Colletti et al. ${ }^{(10)}$ who stated that a common reason for hospitalization in children with acute gastroenteritis is severity of dehydration or mild dehydration accompanied by social factors. The gold standard for determining the degree of dehydration is the child's weight loss ${ }^{(11)}$.

Chest crackles and/or rhonchi was presented in $27.1 \%$ of children who had vomiting due to non-GI causes of vomiting. This is due to lower respiratory tract infection such as pneumonia and acute bronchitis. This agrees with Leung et al. ${ }^{(\mathbf{1 2})}$ who stated that the important physical findings of pneumonia include fever, tachypnea, wheezing, grunting, rhonchi and crackles (rales and crepitations).

The laboratory results shows that the majority of our patients $(82.4 \%)$ complains of vomiting due to GI causes have presented with anemia. The main reason behind this high percentage is that gastroenteritis can be accompanied by malnutrition with reduced iron intake further contributing to the anemia (13). Moreover, the association of $\mathrm{H}$. pylori infection with unexplained Iron deficiency anemia (IDA) has been proven in pediatric populations ${ }^{(14)}$. On the other hand, about $70.8 \%$ of cases with vomiting due to non-GI causes had anemia as well. According to Levy et al. ${ }^{(15)}$, this is because the reduction in hemoglobin level during and after acute or chronic inflammatory diseases is due to many factors such as blocking the iron release, reduction in the intestinal absorption of iron and inhibition or inappropriate erythropoietin production. 
Leukocytosis was present in $40.4 \%$ of cases with vomiting due to GI causes, which is a clinical finding that suggest infection in pediatric patients according to Prusakowski and Chen ${ }^{(16)}$.

Hypoglycemia was present in $19.3 \%$ of cases who had vomiting due to GI causes. This result agrees with Vega and Avva ${ }^{(17)}$, who stated that for patients with vomiting, who were not able to tolerate oral fluids, hypoglycemia might be present.

Positive stool antigen test against $\mathrm{H}$. pylori infection was present in cases diagnosed as $\mathrm{H}$. pylori infection. This agrees with Gisbert et al. ${ }^{(18)}$ who stated that stool antigen test is reliable non-invasive methods for the detection of $\mathrm{H}$. pylori infection that are just as sensitive and specific as the invasive tests. It has good sensitivity and specificity (94\% and 97\% respectively) in global meta-analysis, in the diagnosis of $\mathrm{H}$. pylori infection.

Abdominal U/S has shown a high ability to diagnose renal stones in $12.5 \%$ of cases with non-GI causes of vomiting. This agrees with Jobs et al. ${ }^{(19)}$ who stated that ultrasonography is the most important diagnostic tool in the diagnosis of kidney stone disease.

Signs of inflammation and increased broncho-vascular markings were present in chest radiography of $27.1 \%$ of cases with non-GI causes of vomiting. Chest radiologic changes have been considered the gold standard for defining a pneumonia event according to Le Roux and Zar ${ }^{(20)}$.

\section{REFERENCES}

1. Shields T, Lightdale J (2018): Pediatric vomiting. Pediatr Rev., 39 (7): 342-358.

2. Sreedharan R, Liacouras C (2015): Major Symptoms and Signs of Digestive Tract Disorders. In: Kliegman RM and Behrman RE, eds .Nelson text book of pediatrics. 20th ed. Philadelphia, Elsevier, Pp: 1758-66.

3. Samprathi M, Jayashree M (2017): Child with vomiting. Indian J Pediatr., 84 (10): 787-791.

4. Neil M (2009): Vomiting in the Pediatric Age Group. Pediatr Health, 3 (5): 479-503.

5. Allen K (2007): The vomiting child--what to do and when to consult. Aust Fam Physician, 36 (9): 684-7.

6. Cherry J, Harrison G, Kaplan S et al. (2018): Feigin and Cherry's textbook of pediatric infectious diseases: Elsevier, Pp: 245-256. https://www.elsevier.com/books/feigin-and-cherrys- textbook-of-pediatric-infectious-diseases/unknown/9780-323-39281-5

7. Operario D, Platts-Mills J, Nadan S et al. (2017): Etiology of severe acute watery diarrhea in children in the global rotavirus surveillance network using quantitative polymerase chain reaction. J Infect Dis., 216 (2): 220-7.

8. Kamel A, Ali M, El-Nady H et al. (2011): Presence of enteric hepatitis viruses in the sewage and population of Greater Cairo (2011). Clin Microbiol Infect., 17: 11821185.

9. WHO scale of dehydration (2005): The treatment of diarrhoea. A manual for physicians and other senior health workers. https://apps.who.int/iris/bitstream/handle/ 10665/43209/ 9241593180.pdf; jsessionid=6B08BE77D3EA57DC5A6 7EFA0A43D6A33? sequence $=1$

10. Colletti J, Brown K, Sharieff G et al. (2010): The management of children with gastroenteritis and dehydration in the emergency department. J Emerg Med., 38: 686-698.

11. Florez I, Niño-Serna L, Beltrán-Arroyave C (2020): Acute Infectious Diarrhea and Gastroenteritis in Children. Current Infectious Disease Reports, 22 (2): 4 -9.

12. Leung A, Wong A, Hon $K$ (2018): CommunityAcquired Pneumonia in Children. Recent Pat Inflamm Allergy Drug Discov., 12 (2): 136-144.

13. Gisbert J, Gomollón F (2009): Classification of anemia for gastroenterologists. World J Gastroenterol., 15: 4627- 37.

14. Ortiz M, Rosado-Carrion B, Bredy R (2014): Role of helicobacter pylori infection in Hispanic patients with anemia. Bol Asso Med P R., 106: 13-8

15. Levy A, Fraser D, Rosen S et al. (2005): Anemia as a risk factor for infectious diseases in infants and toddlers: Results from a prospective study. Eur J Epidemiol., 20: 27784.

16. Prusakowski M, Chen A (2017): Pediatric Sepsis. Emerg Med Clin North Am., 35 (1): 123-138.

17. Vega R, Avva U (2020): Pediatric Dehydration. In: StatPearls . Treasure Island (FL): StatPearls Publishing, Pp: $1-5$.

https://www.ncbi.nlm.nih.gov/books/NBK436022/

18. Gisbert J, de la Morena F, Abraira V (2006): Accuracy of monoclonal stool antigen test for the diagnosis of $\mathrm{H}$. pylori infection: a systematic review and meta-analysis. Am J Gastroenterol., 101: 1921-1930.

19. Jobs K, Rakowska M, Paturej A (2018): Urolithiasis in the pediatric population - current opinion on epidemiology, patophysiology, diagnostic evaluation and treatment. Dev Period Med., 22 (2): 201-208.

20. Le Roux D, Zar H (2017): Community-acquired pneumonia in children - a changing spectrum of disease. Pediatr Radiol., 11: 1392-1398. 